\title{
PRELIMINARY STUDIES ON A HOST ATTRACTANT OF THE COCONUT PEST. RHYNCHOPHORUS FERRUGINEUS (COLEOPTERA : CURCULIONIDAE)
}

\author{
NEELAKANTHI E. GUNAWARDENA AND RENUKA GUNATILAKE \\ Department of Chemistry, University of Kelaniya, Kelaniya.
}

(Date of receipt $\quad: \quad 26$ September 1992)
(Date of acceptance : 08 March 1993)

\begin{abstract}
Rhynchophorus ferrugineus one of the major pests of coconut palm, (Cocos nucifera) was used in an olfactometer bioassay to investigate the attractants present in young coconut bark. Males and females were equally attracted to the arm of the olfactometer baited with steam volatiles from freshly cut young coconut bark in significant numbers. Soxhlet extracts of the residue from steam distillate did not show any activity. Bioassay guided preparative thin layer chromatographic fractionation of the total steam distillate yielded two active fractions showing the multicomponent nature of this attractant. These fractions also possessed long range attractant properties.
\end{abstract}

Bioassay on unfermented coconut sap (sweet toddy), and some simple alcohols, viz cthyl alcohol, isopropyl alcohol and isoamyl alcohol also showed significant activity $(p<0.01$ ) in the olfactometer assay. These compounds, however, did not possess long range attractant properties.

Field attractiveness of these compounds were found to be poor. Total steam distillate in ethyl alcohol proved to be an effective bait, although less efficient than the natural source viz. the fermenting coconut bark. Either ethyl alcohol or amyl alcohol alone was not effective as baits.

Key words: host attractants, Rhynchophorus ferrugineus, coconut pest, steam volatiles, alcohols.

\section{INTRODUCTION}

In Sri Lanka, the coconut palm is susceptible to several insects and mites. ${ }^{1}$ Rhynchophorus ferrugineus, commonly known as the red weevil, is one of the five major pests in Sri Lanka. Female $R$. ferrugineus is reported to lay an average of 123 eggs during a 30 day period of which 114 are viable. ${ }^{1}$ The larvae burrow into fresh tissues and then find their way to the bud and also the heart of the crown of the palm. Here they congregate and feed further for a period of $2-4$ months. As a result infected palms lose their crowns completely.

Difficulties are encountered in detecting infected coconut trees before they are destroyed. ${ }^{2}$ The present method of control recommended by the Coconut Research Institute, Lunuwila, Sri Lanka, involves drilling holes into the soft bud region of the infested palm and pouring any insecticide containing monocrotophos. ${ }^{3}$ This practice however is not satisfactory because it only kills those larvae which come into contact with the insecticide and because the palm can be saved only if treated early during 
infestation. The hazardous nature of the operation and possible environmental pollution with insecticide are other concerns arising from the use of this method. Another approach involves the use of an electronic device for detecting red weevils inside the coconut trunk. ${ }^{4}$ This method, however, is expensive for routine use. Little is known about the chemical ecology of the Rhynchophorus species. A male aggregation pheromone has been recently identified in the American palm weevil, $R$. palmanim. ${ }^{5}$ The fermenting sap oozing from wounded coconut palms is known to attract red weevils to the palm ${ }^{6}$ in Sri Lanka. A chemical was thought to be released from the damaged tissue which could help red weevils to find the plant. Attraction of insects to host volatiles is known to occur in several coleopterans 7,8 , including curculionids. ${ }^{9}$ The useful role of insect pheromone attractants in integrated pest management strategies, ${ }^{10}$ and the mass trapping of Glischrochilus species $11,12,13$ with odour baits suggest the use of host attractants as an alternative to conventional pesticides. The hypothesis used is that a trap baited with an attractant (or more probably a synthetic equivalent) in the field will attract pests in the area. If the trap catch is high, this would be a means of reducing the pest population. On the other hand if the trap catch is low, at least the information would demonstrate the presence of the pest in the area so that suitable precautions may be taken. ${ }^{10}$

This paper reports the results of a preliminary study to investigate the presence of chemical attractants in the sap of coconut bark to $R$. ferrugineus.

\section{METHODS AND MATERIALS}

Steam distillate and soxhlet extract: Young coconut bark was cut into small pieces and steam distilled for $5 \mathrm{~h}$. The aqueous layer which resulted was saturated with $\mathrm{NaCl}$ and extracted with $3 \times 200 \mathrm{ml}$ diethyl ether GPR grade, (BDH London). The ether phase was dried over magnesium sulfate and concentrated in vacuo down to $20 \mathrm{ml}$. Due to the volatile nature of the attractants the solvent was not completely removed from the extract and a concentrated ether solution was used in all experiments. The residue from the steam distillate was subjected to soxhlet extraction with methanol for $6 \mathrm{~h}$ and the solution which resulted was concentrated in vacuo.

Fractionation of the total extract: A concentrated solution of the steam volatiles was introduced onto two preparative tlc plates $\left(20 \mathrm{~cm} \times 20 \mathrm{~cm}\right.$, Silica gel $F_{254}$, Aldrich Chemical Co., UK) and developed with the solvent system, petroleum ether and methylene chloride (3:1). Seven bands corresponding to $R f$ values of $0.25,0.31,0.40$, $0.52,0.66,0.76,0.91$ were cut and eluted with diethyl ether. Each fraction was concentrated to $1 \mathrm{ml}$ and tested for biological activity.

Laboratory Bioassay: Larvae of $R$. ferrugineus obtained from an infested coconut palm were introduced into a freshly cut young coconut trunk which was placed in a wooden 
cage fitted with a wire mesh for ventilation. Adults emerging from the trunk were transferred into a moist container and were fed with sugar cane/10\% sugar solutions. Laboratory temperature was maintained at $29^{\circ} \mathrm{C} \pm 2^{\circ} \mathrm{C}$ and relative humidity at 80 $+4 \%$. All bioassays were done between $1000-1300 \mathrm{~h}$ and the bioassay was not repeated on insects on the same day.

Bioassay for short range activity: Choice test was performed in a Y-shaped olfactometer ${ }^{14}$ using $0.1 \mathrm{ml}$ of the test substance (concentrated total extract, fractions 3 and 4 , neat alcohols and distilled water) in the baited arm. Baits were prepared by introducing $0.1 \mathrm{ml}$ of the substance onto filter paper and allowing the solvent to evaporate. In the same manner blanks were prepared using diethyl ether. Baits were introduced into one arm and the blanks to the other arm of the $Y$ tube. Immediately afterwards, a slow stream of air was passed through both arms, A and B and the insect tube containing $5-12$ insects at a time was fitted into the stem of the $Y$ tube. Each substance was tested with 6-15 batches of insects. Among those insects moving forward their ability to choose the baited arm was considered the criterion for activity ${ }^{15}$ in this assay. Hence the number of insects moved to each arm were counted after 2 min. Mean percentages of weevils attracted to arm A and B were compared by the Student's t test.

Bioassay for long range activity: A long tunnel made with PVC rings and polythene lining ( $12 \mathrm{~cm}$ diameter $\times 3.0 \mathrm{~m}$ in length) was used (Figure 1$)$. The bait was kept inside one end (A) of the tube and insects were released from the other end (C) while maintaining a slow stream of air over the bait towards the insects. Movement of insects towards the bait was the criterion for attraction. ${ }^{16}$ Hence the number of insects in part A of the tube was counted after a period of $5 \mathrm{~min}$.

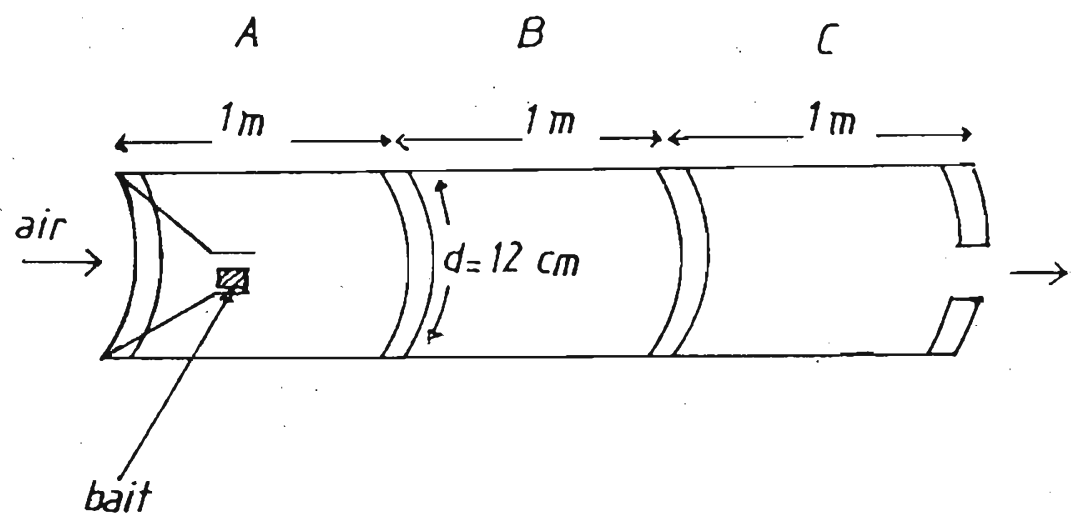

Figure 1: The wind tunnel used in the long range activity bioassay of test compounds with $R$. ferrugineus. 
Field testing: Field tests were carried out following the guidelines described by Carde and Elkinton. ${ }^{17}$ Metal boxes $(31 \mathrm{~cm} \times 16.5 \mathrm{~cm} \times 10 \mathrm{~cm})$ were fitted with a wire mesh on top (Figure 2). The inner surface of these boxes treated with glue (polybutene, Nissaki) were kept at a height of $4 \mathrm{ft}$ adjacent to coconut palms. Bait $(5 \mathrm{ml}$ of concentrated solutions/ neat liquids) in polyethylene vials (Aldrich Chemical Co, UK) was hung inside the trap. Each bait was tested in triplicate. The traps were set $25 \mathrm{~m}$ apart and were placed in coconut fields at Lunuwila and Kelaniya. The trap catch for each bait was noted daily for 14 days.
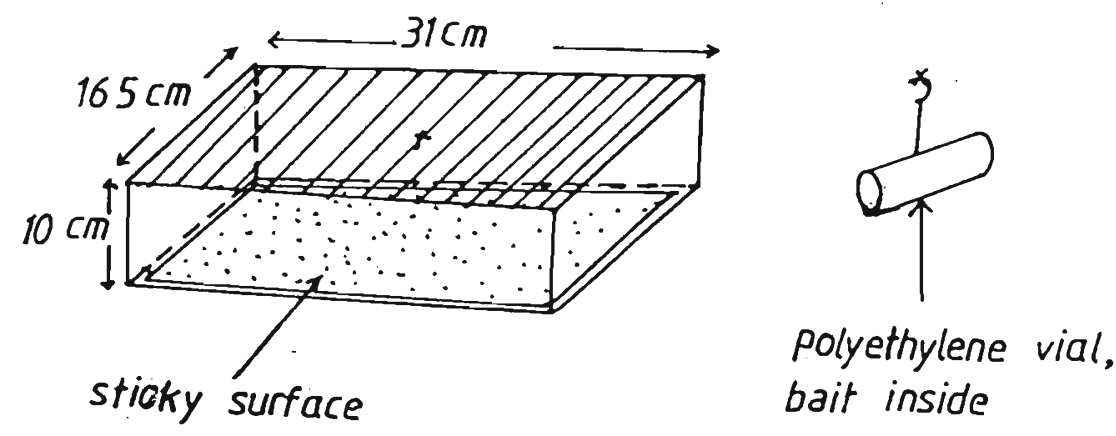

Figure 2: The trap used in field trapping of $R$. ferrugineus.

\section{RESULTS}

\section{Biological activity}

Adult red weevils lived for approximately 2 months, but responded well towards attractants only during the first two weeks after emergence. Hence only insects less than two weeks old were used in the assay. In general, males responded faster than females.

\section{Short range activity}

Snout movements followed by rapid movement of insects towards the $\mathrm{Y}$ junction of the olfactometer followed by the selection of the baited arm within minutes was seen as responses to attractants. Non-attractants did not elicit these responses and $80 \%$ insects remained in the insect tube or part $\mathrm{C}$ of the olfactometre. 
Steam distillate of the coconut bark, tlc fractions $3\left(R_{f} 0.31\right)$ and $4\left(R_{f} 0.41\right)$ were attractive to both males and females, with the mean percentage of insects choosing the baited arm being $65.1 \% \pm 4.8,68.5 \% \pm 7.1$ and $72.1 \% \pm 3.7$ respectively (Table 1). In all these cases the mean number of insects selecting the baited arm differed significantly from the non baited arm (Student's t-test, $\mathrm{p}<0.01$ ). $85.8 \%$ insects did not move forward with the soxhlet extracts as bait and no preference was seen for the baited arm. Similar behaviour was observed when distilled water was used as the bait. (Table 1). Alcohols elicited highest activity in the ôlfactometer assay. Isopropyl and isoamyl alcohols elicited higher responses than ethyl alcohol. Sweet toddy elicited a similar level of response to that of isopropyl alcohol (Table 1).

Table 1: Olfactometer bioassay with adult male and female $R$. fernugineus

\begin{tabular}{|l|c|c|c|c|c|c|}
\hline \multicolumn{3}{|c|}{} & \multicolumn{3}{|c|}{$\begin{array}{c}\text { \% mean of insects + selecting } \\
\text { arms of olfactometer }\end{array}$} & $\begin{array}{l}\% \text { mean of } \\
\text { insects not } \\
\text { responding }\end{array}$ \\
\hline $\begin{array}{l}\text { Test } \\
\text { substance }\end{array}$ & $\begin{array}{c}\text { Total no } \\
\text { insects }\end{array}$ & $\begin{array}{c}\text { No. of } \\
\text { batches } \\
\text { (n) }\end{array}$ & $\begin{array}{c}\text { baited } \\
\text { arm } \\
\text { A }\end{array}$ & $\begin{array}{c}\text { non-baited } \\
\text { arm*** } \\
\text { B }\end{array}$ & p & $\begin{array}{l}\text { Insect tube } \\
+ \text { C arm }\end{array}$ \\
\hline $\begin{array}{l}\text { Distilled } \\
\text { water }\end{array}$ & 85 & 10 & $8.0 \pm 2.9$ & $8.2 \pm 1.5$ & n.s & $83.8 \pm 3.2$ \\
\hline $\begin{array}{l}\text { Steam } \\
\text { distillate }\end{array}$ & 90 & 11 & $65.1 \pm 4.8$ & $9.6 \pm 3.4$ & $<0.01$ & $25.3 \pm 5.2$ \\
\hline $\begin{array}{l}\text { Soxhlet } \\
\text { extract }\end{array}$ & 160 & 17 & $6.5 \pm 2.2$ & $7.6 \pm 1.6$ & n.s & $85.8 \pm 2.6$ \\
\hline Sweet toddy & 104 & 12 & $78.6 \pm 5.4$ & $17.0 \pm 5.0$ & $<0.01$ & $4.4 \pm 1.6$ \\
\hline $\begin{array}{l}\text { Ethyl } \\
\text { alcohol }\end{array}$ & 94 & 12 & $73.0 \pm 5.6$ & $17.1 \pm 4.4$ & $<0.01$ & $9.9 \pm 3.1$ \\
\hline $\begin{array}{l}\text { Isopropyl } \\
\text { alcohol }\end{array}$ & 97 & 11 & $80.3 \pm 4.4$ & $10.6 \pm 2.5$ & $<0.01$ & $9.1 \pm 3.3$ \\
\hline $\begin{array}{l}\text { Isoamyl } \\
\text { alcohol }\end{array}$ & 111 & 13 & $79.0 \pm 4.0$ & $14.1 \pm 3.1$ & $<0.01$ & $6.9 \pm 2.4$ \\
\hline Fraction -3 & 40 & 6 & $68.5 \pm 7.1^{*}$ & $15.3 \pm 8.4$ & $<0.01$ & $19.2 \pm 3.9$ \\
\hline Fraction-4 & 40 & 6 & $72.1 \pm 3.7$ & $10.4 \pm 2.1$ & $<0.01$ & $17.5 \pm 3.4$ \\
\hline
\end{tabular}

\# $0.1 \mathrm{ml}$ of the concentrated solutions were used in the case of stean distillate and fractions (3 and 4$)$. Same amounts of the neat liquids were used in the case of alcohols.

Each batch consisted of 5-12 unsexed insects

+ Only those moved forward and passed the $Y$-junction were considered in statistical analysis (Student's t test).

* Values are mean \pm standard error of the mean. 


\section{Long range activity}

Orientation in the direction of the bait and preflight wingfanning were seen along with the major criterion for activity used in the assay viz. the movement into section $\mathrm{A}$ (Figure 1) where the bait was kept. In this experiment the total extract and the tlc fraction 4 showed the highest activities. tlc fraction 3 was less active (Table 2). Ethyl alcohol and isopropyl alcohol were inactive in the long range assay (Table 2).

Table 2: Long range attractants of $R$. ferrugineus.

\begin{tabular}{|c|c|c|c|}
\hline Bait & $\%$ A & $\% \mathrm{~B}$ & $\% \mathrm{C}$ \\
\hline 1. Ethyl alcohol & 00 & 13 & 86 \\
\hline 2. Isopropyl alcohol & 00 & 06 & 93 \\
\hline 3. Fraction 3 & 53 & 30 & 16 \\
\hline 4. Fraction 4 & 76 & 16 & 06 \\
\hline 5. Total extract & 83 & 10 & 06 \\
\hline
\end{tabular}

* Total number of 10 insects were used in each assay and the results are mean percentages of three replicate assays in each section of the wind tunnel.

\section{Field assay}

Both males and females were caught in traps in approximately equal numbers. The baits containing a mixture of ethyl alcohol and steam distillate and fermenting exposed coconut bark, caught weevils while ethyl alcohol, amyl alcohol and the blank caught no weevils (Table 3 ).

Table 3: Field trapping of $R$. Fernugineus with bait.

\begin{tabular}{|c|c|}
\hline Bait & Mean* no of red weevils trapped 14 days \\
\hline 1. Ethyl alcohol & 00 \\
\hline 2. Amyl alcohol & 00 \\
\hline $\begin{array}{l}\text { 3. Steam distillate: } \\
\text { Ethyl alcohol }(1: 1, w / w)\end{array}$ & 1.0 (range $0-2$ ) \\
\hline 4. Fermenting Coconut bark & 6.3 (range $5-8$ ) \\
\hline 5. Blank & 00 \\
\hline
\end{tabular}

* Run June $6^{\text {th }} \cdot 20^{\text {th }}$ and July $1^{\text {st }}-15^{\text {th }} 1987$, Coconut Estate, Lunuwila and Waragoda, Kelaniya Sri Lanka. Results are means of three replicates.

\# $5 \mathrm{ml}$ of the concentrated solutions/neat liquids were used in polyethylene vials 


\section{DISCUSSION}

Attraction of $R$. fermigineus to the total steam distillate of coconut bark and it's tic fractions, sweet toddy and some lower alcohols was shown in laboratory assays. In both long and short range assays, movement of insects in the direction of the bait was the most prominent response. These data are in agreement with that for the palm weevil Rhynchophonus palmanim which was also shown to be attracted to coconut stem tissue. ${ }^{18}$

Fractionation of the total steam distillate resulted in two fractions having long range attractant properties. This indicates the involvement of specific volatile compounds that are responsible for luring this pest from long distances. Such substances can have practical applications in the control of $R$. ferrugineus. From structure-activity relationships already known in the field of insect attractants, chirality and the presence of specific olefinic bonds are important in long range attraction ${ }^{19}$ Therefore ethyl alcohol and iso propyl alcohol may not be important in luring the weevil from a long distance and this is confirmed by our results. But such small molecules may play an important role at a short range. Strong attractant properties of the lower alcohols at short range is evident from our olfactometer assays. It is therefore possible that both types of attractant are important for the pest to find a wounded coconut palm.

Field results were encouraging only with a mixture of ethyl alcohol and the steam distillate. Since fermenting coconut bark, under the same conditions, caught nearly double the number of weevils, the results indicate some missing components in the mixture. Field experiments also need to be improved with respect to the binder trap design etc.

The identification of chemicals responsible for attraction is the next step in our study. Only recently a number of attractants have been identified in the family Curculinoidae. For example, Anthonomus grandis (Curculinoidae) has been found to possess receptors ${ }^{9}$ for $\beta$-caryophyllene, $\quad$ trans-2-hexen-1-ol, $\quad \mathrm{t}$ - $\beta$-ocimene, benzaldehyde, linalool and $\beta$-bisabolol which are it's host plant volatiles. Similarly the aggregation pheromone of the American palm weevil, Rhynchophonis palmarum (Curculionidae) has been identified ${ }^{5}$ as (2E)-6-methyl-2-hepten-4-ol. Considering the above, and the results of our preliminary studies it is possible to expect a multicomponent attractant with much polar character, possibly chiral alcohols. A report on $R$. palmanim ${ }^{18}$ suggests that this pest can be trapped successfully with an artificial bait containing malt, skatol, and isoamyl acetate with a catch of 191 insects/14 days, compared with coconut stem tissue which caught only 50 insects under the same conditions. This result is interesting because the artificial lure performed better than the natural attractant. 


\section{Acknowledgements}

This investigation was supported by the International Foundation for Science, Sweden (F/936-2) and the Natural Resources, Energy and Science Authority (RG/87/B/5). The advice and the assistance of Dr P. Kanagaratnam, former Head, Crop Protection Division, Coconut Research Institute, Lunuwila, is gratefully acknowledged.

\section{References}

1. . Pinto J.L.J.G. (1984). Red weevil pest of coconut, Coconut Bulletin, Coconut Research Board of Sri Lanka. 1(2):36.

2. Report of the crop protection division (1975). Coconut Quarterly 26:51-56.

3. Estate management and pest control, Advisory Leaflet, No. 37 and 50, Coconut Research Institute, Lunuwila, Sri Lanka.

4. An electronic device for the detection of red weevil infestations. (1971). Coconut Research Board, Lunuwila, Sri Lanka.

5. Rochar D., Malosse C., Lettere M., Ducrot P., Zagatti P., Renou M. \& Descoins C. (1991). Male produced aggregation pheromone of the American palm wcevil, Rhynchophorus palmanum (Coleoptera, Curculionidae): Collection, identification, electrophysiological activity and laboratory bioassay. Joumal of Chemical Ecology 17:2127-2141.

6. Gunatilake R. \& Gunawardena N.E. (1986). Ethyl alcohol: A major attractant of Red Weevil (Rhynchophonus fernugineus). Proceedings of the Sri Lanka Association for the Advancement of Science 42:70.

7. Lin H. \& Phelan P.L. (1991). Identification of food volatiles attractive to Glischrochilus quadrisiqnatus and G. faciatus (Coleoptera: Nitidulidae). Journal of Chemical Ecology, 17:1273-1286.

8. Lin H. \& Phelan P.L. (1991). Identification of food volatiles attractive to Carpophilus luqubris (Colcoptera: Nitidulidae). Joumal of Chemical Ecology

9. Dickens J.C. (1990). Specialized receptor neurons for pheromones and host plant odors in the boll weevil. Anthonomus grandis Boh (Coleoptera: Curculinoidae). Chennical Senses 15(3):311-331.

10. Champion D.G. (1984). Survey of pheromone uses in pest control. In Techniques in pheromone research (Eds. Hummel H.E. \& Miller T.A.) pp. 406-449. Springer
and Verlag. New York 
11. Warner R.W. (1960). Area baiting to control drosophila and nitidulid beetles. pp. 35-38. Proceedings, $14^{\text {th }}$ Annual Research Conference Fig Institute, Califonia.

12. Pree D.J. (1969). Control of Glischrochilus quadrisiqnatus (Say) (Coleoptera: Nitiduliadae) a pest of fruit and vegetables in southern Ontario. Proceedings of Entomological Society, Ontario. 99: 6-64:

13. Foott, W.H. \& Hybsky J.E. (1976). Capture of Glischrochilus quadrisignatus (Coleoptera: Nitidulidae) in bait traps 1970-1974. Canadian Entomologist 108:837-839.

14. Gunawardena N.E., Attygalle A.B. \& Herath H.M.W.K.B. (1989). The sex pheromone of the brinjal pest Leucinodes orbonalis Guenie (Lepidoptera): Problems and perspectives, Joumal of the National Science Council of Sri Lanka. 17(2):165-175.

15. Baker T.C. \& Carde R.T. (1984). Techniques for behavioural bioassays. In Techniques in pheromone research (Eds. Hummel, E.A. and Miller T.A.) pp. 45-73 Springer and Verlag. New York.

16. Baker T.C. \& Linn C.E. Jr. (1984). Wind tunnels in pheromone research. In Techniques in pheromone research (Eds. Hummel E.A. \& Miller T.A.) pp. 75-110. Springer \& Verlag, New York.

17. Cardel R.T: \& Elkinton J.S. (1984). Field trapping with attractants: methods and interpretation. In Techniques in pheromone research (Eds. Hummel E.A. \& Miller T.A.) pp. 111-129. Springer \& Verlag, New York.

18. Hangley E.A.C. (1965). Tests of attractants for the Palm Weevil. Joumal of Economic Entomology 58(5): 1002-1003.

19. Mori K. (1984). The significance of chirality: methods of determining absolute configuration and optical purity of pheromones and related compounds. In Techniques in pheromone research (Eds., Hummel H.E. and Miller T.A. Miller). pp. 323-370. Springer and Verlag, New York. 